\title{
Distribution and fate of selected oxygenated organic species in the troposphere and lower stratosphere over the Atlantic
}

\section{Citation}

Singh, H., Y. Chen, A. Tabazadeh, Y. Fukui, I. Bey, R. Yantosca, D. Jacob, et al. 2000. “Distribution and Fate of Selected Oxygenated Organic Species in the Troposphere and Lower Stratosphere over the Atlantic." Journal of Geophysical Research 105 (D3): 3795. doi:10.1029/1999jd900779.

\section{Published Version}

doi:10.1029/1999JD900779

\section{Permanent link}

http://nrs.harvard.edu/urn-3:HUL.InstRepos:14118166

\section{Terms of Use}

This article was downloaded from Harvard University's DASH repository, and is made available under the terms and conditions applicable to Other Posted Material, as set forth at http:// nrs.harvard.edu/urn-3:HUL.InstRepos:dash.current.terms-of-use\#LAA

\section{Share Your Story}

The Harvard community has made this article openly available.

Please share how this access benefits you. Submit a story.

\section{Accessibility}




\title{
Distribution and fate of selected oxygenated organic species in the troposphere and lower stratosphere over the Atlantic
}

\author{
H. Singh, ${ }^{1}$ Y. Chen, ${ }^{1}$ A. Tabazadeh, ${ }^{1}$ Y. Fukui, ${ }^{1}$ I. Bey, ${ }^{2}$ R. Yantosca, ${ }^{2}$ D. Jacob, ${ }^{2}$ \\ F. Arnold, ${ }^{3}$ K. Wohlfrom, ${ }^{3}$ E. Atlas, ${ }^{4}$ F. Flocke, ${ }^{4}$ D. Blake,${ }^{5}$ N. Blake, ${ }^{5}$ B. Heikes, ${ }^{6}$ \\ J. Snow, ${ }^{6}$ R. Talbot, ${ }^{7}$ G. Gregory, ${ }^{8}$ G. Sachse, ${ }^{8}$ S. Vay, ${ }^{8}$ and Y. Kondo ${ }^{9}$
}

\begin{abstract}
A large number of oxygenated organic chemicals (peroxyacyl nitrates, alkyl nitrates, acetone, formaldehyde, methanol, methylhydroperoxide, acetic acid and formic acid) were measured during the 1997 Subsonic Assessment (SASS) Ozone and Nitrogen Oxide Experiment (SONEX) airborne field campaign over the Atlantic. In this paper, we present a first picture of the distribution of these oxygenated organic chemicals (Ox-organic) in the troposphere and the lower stratosphere, and assess their source and sink relationships. In both the troposphere and the lower stratosphere, the total atmospheric abundance of these oxygenated species ( $\Sigma \mathrm{Ox}$-organic) nearly equals that of total nonmethane hydrocarbons ( $\Sigma N M H C)$, which have been traditionally measured. A sizable fraction of the reactive nitrogen (10-30\%) is present in its oxygenated organic form. The organic reactive nitrogen fraction is dominated by peroxyacetyl nitrate (PAN), with alkyl nitrates and peroxypropionyl nitrate (PPN) accounting for $<5 \%$ of total $\mathrm{NO}_{y}$. Comparison of observations with the predictions of the Harvard three-dimensional global model suggests that in many key areas (e.g., formaldehyde and peroxides) substantial differences between measurements and theory are present and must be resolved. In the case of $\mathrm{CH}_{3} \mathrm{OH}$, there appears to be a large mismatch between atmospheric concentrations and estimated sources, indicating the presence of major unknown removal processes. Instrument intercomparisons as well as disagreements between observations and model predictions are used to identify needed improvements in key areas. The atmospheric chemistry and sources of this group of chemicals is poorly understood even though their fate is intricately linked with upper tropospheric $\mathrm{NO}_{x}$ and $\mathrm{HO}_{x}$ cycles.
\end{abstract}

\section{Introduction}

Oxygenated hydrocarbon species have the potential to play an important role in processes of atmospheric ozone formation [Loyd, 1979; Singh et al., 1995; Wennberg et al., 1998]. Unlike most hydrocarbons, many oxygenated species can be photolyzed throughout the troposphere. Carbonyls and peroxides are potential sources of $\mathrm{HO}_{x}$ free radicals, and molecules such as acetone can form peroxyacetyl nitrate (PAN) in the up-

\footnotetext{
'Earth Science Division, NASA Ames Research Center, Moffett Field, Califorma.

${ }^{2}$ Department of Earth and Planetary Sciences, Harvard University, Cambridge, Massachusetts.

${ }^{3}$ Max Planck Institute für Kemphysik, Heidelberg, Germany.

${ }^{4}$ Atmospheric Chemistry Division, National Center for Atmospheric Research, Boulder, Colorado.

${ }^{5}$ Department of Chemistry, University of California, Irvine.

${ }^{6}$ Center for Atmosphenc Chemistry Studies, University of Rhode Island, Narragansett.

Institute for the Study of Earth, Oceans, and Space, University of New Hampshire, Durham.

${ }^{8}$ Earth Science Division, NASA Langley Research Center, Hampton, Virginia.

${ }^{9}$ Solar Terrestrial Environmental Laboratory, Nagoya University, Toyokawa, Japan.
}

Copyright 2000 by the American Geophysical Union.

Paper number 1999JD900779.

0148-0227/00/1999JD900779\$09.00 per troposphere (UT) and sequester reactive nitrogen [Singh et al., 1995; Jaeglé et al., 1997; Wennberg et al., 1998; Crawford et al., 1999]. In general, measurements of organic oxygenated species in remote troposphere are extremely sparse and often limited to a few species. In the stratosphere, these measurements are virtually nonexistent [Singh et al., 1997]. The Subsonic Assessment (SASS) Ozone and Nitrogen Oxide Experiment (SONEX)/DC-8 airborne field campaign of October/November 1997, with its focus on the $\mathrm{NO}_{x}-\mathrm{HO}_{x}-\mathrm{O}_{3}$ chemistry, provided a unique opportunity to characterize the distribution of several important oxygenated organic species in the troposphere and the "lowermost" stratosphere (LS) over the Atlantic. An overview of the SONEX mission has been provided by Singh et al. [1999].

In this paper, we provide a description of the atmospheric distribution of select oxygenated organic species as measured during the 1997 SONEX mission. These species include organic nitrates (peroxyacyl nitrates, alkyl nitrates), carbonyls (acetone, formaldehyde), alcohols (methanol, ethanol), peroxides (methylhydroperoxide), and acids (acetic acid, formic acid). Instrumentation and measurement methods are not described here but have been previously published [Singh et al., 1999; Schumann et al, 1999; and references therein]. SONEX/DC-8 and the Pollution From Aircraft Emissions in the North Atlantic Flight Corridor (POLINAT-2)/Falcon aircraft platforms also offered limited opportunities for instrument intercomparisons and these results are discussed. In addition, the Harvard three-dimensional (3-D) global model has been used to 
compare these observations with model predictions. We also provide an assessment of the sources and sinks of these chemicals.

\section{Discussion of Results}

It is pertinent to note that during SONEX attention was focused on the UT region of the atmosphere that has been previously minimally studied. SONEX objectives also were such that much of the data were collected between $40^{\circ}-65^{\circ} \mathrm{N}$ latitudes with only one flight going as far south as $20^{\circ} \mathrm{N}$. The stratosphere was frequently sampled although $\mathrm{O}_{3}$ concentrations never exceeded $450 \mathrm{ppb}$, and $\mathrm{N}_{2} \mathrm{O}$ was never below 300 $\mathrm{ppb}$. This region of the stratosphere has been commonly defined as the "lowermost stratosphere" (LS). With this perspective in mind, a greater emphasis is placed on the UT/LS regions. Only SONEX data collected on the DC-8 are used in this study. POLINAT Falcon data are occasionally considered for purposes of comparisons.

The SONEX NO $y$ data were examined against several tracers that may be used to distinguish the stratosphere from the troposphere $\left(\mathrm{O}_{3}, \mathrm{~N}_{2} \mathrm{O}\right.$, and $\left.\mathrm{CO}\right)$. It was determined that a s1mple filter $\left(\mathrm{O}_{3}>100 \mathrm{ppb}\right.$ and $\left.\mathrm{Z}>6 \mathrm{~km}\right)$ was adequate to define periods of stratospheric influences. This filter has been applied to all tropospheric/stratospheric observations discussed here. Tro- pospheric observations have also been compared with the Harvard 3-D global model ( $4^{\circ}$ latitude $\times 5^{\circ}$ longitude grid size), an earlier version of which has been described by Wang et al. [1998a, b]. The present version has improved descriptions of chemistry and emissions, and higher vertical resolution (20 layers versus 9 layers) making it more appropriate for upper tropospheric simulations. The model transports 24 tracers, including odd oxygen $\left(\mathrm{O}_{x}=\mathrm{O}_{3}+\mathrm{NO}_{2}+2 \mathrm{NO}_{3}\right), \mathrm{NO}_{x}, \mathrm{HNO}_{3}$, $\mathrm{N}_{2} \mathrm{O}_{5}, \mathrm{HNO}_{4}$, three peroxyacyl nitrates, a lumped alkyl nitrate, $\mathrm{CO}$, alkanes (ethane, propane, higher alkanes), alkenes, isoprene, carbonyls (acetone and higher alkyl ketones, formaldehyde, and higher alkyl aldehydes, methacrolein, methylvinyl ketone), and peroxides $\left(\mathrm{H}_{2} \mathrm{O}_{2}, \mathrm{CH}_{3} \mathrm{OOH}\right)$. A present shortcoming is that the model contains 1993 meteorology. Comparison of the 1993 simulation with SONEX observations should still be useful in terms of mean concentrations and concentration gradients. Fuelberg et al. [this issue] conclude that, within the normal year-to-year variability, 1997 was a climatologically average year. In the following section, we shall discuss the distribution, sources, and sinks of selected organic species in the troposphere and the LS.

\subsection{Tropospheric Distributions}

Figure 1 shows the vertical distribution of $\mathrm{O}_{3}$ and $\mathrm{CO}$ (a useful tracer) as observed during SONEX over the North Atlantic
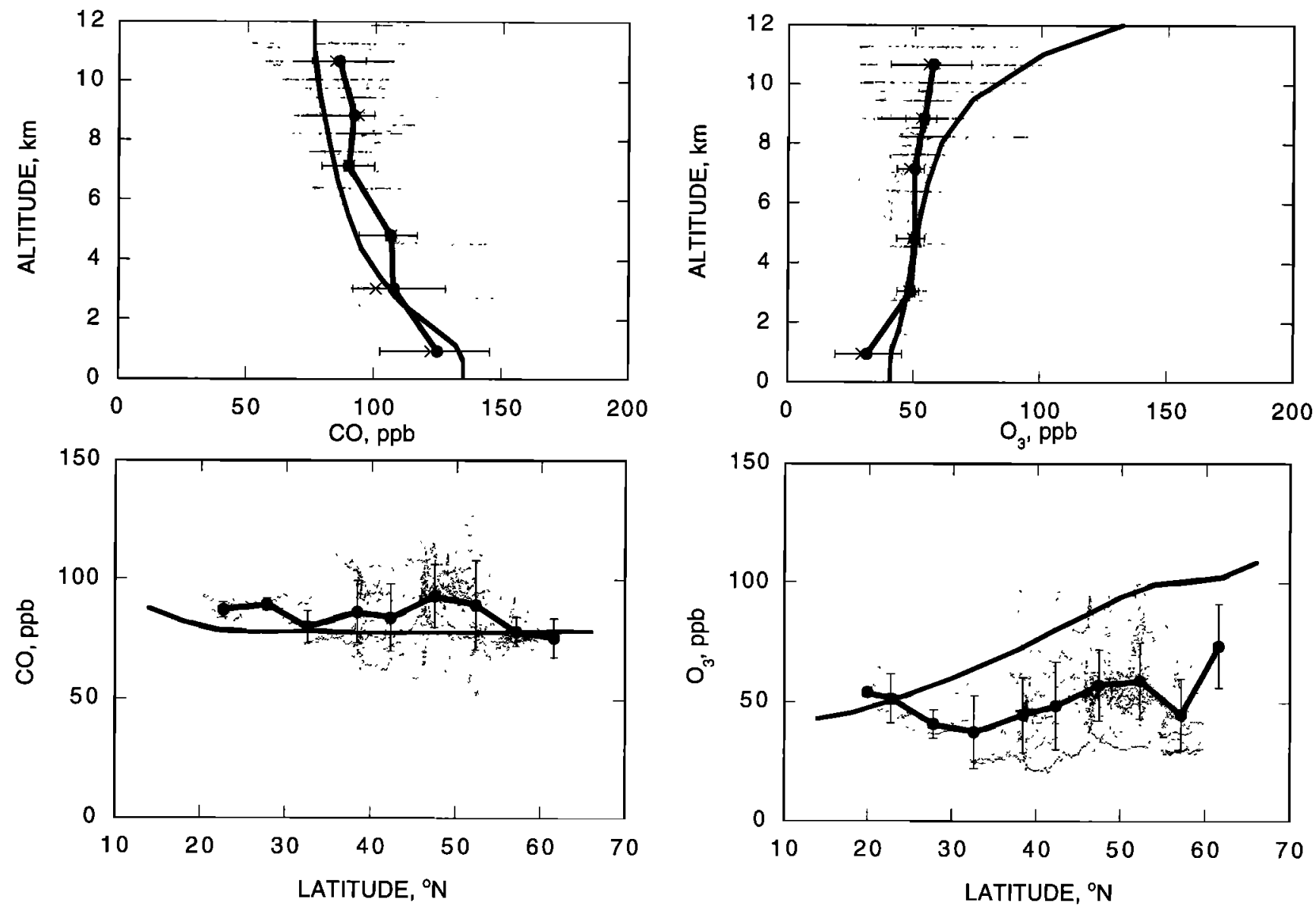

Figure 1. Tropospheric vertical and latitudinal distribution of $\mathrm{O}_{3}$ and $\mathrm{CO}$ over the Atlantic during SONEX. Periods of stratospheric influences $\left(\mathrm{O}_{3}>100 \mathrm{ppb} ; \mathrm{Z}>6 \mathrm{~km}\right)$ are excluded. The vertical structure is for $45^{\circ}-65^{\circ} \mathrm{N}$ with averages calculated over $2-\mathrm{km}$ bins. Latitudinal distribution is for the upper troposphere based on data collected between $8-12 \mathrm{~km}$ with averages calculated over $5^{\circ}$ bins. Results from the Harvard 3-D global model are averaged over $5^{\circ}-70^{\circ} \mathrm{W}$ longitude (SONEX regime) and are shown in similar lines (no data points). 

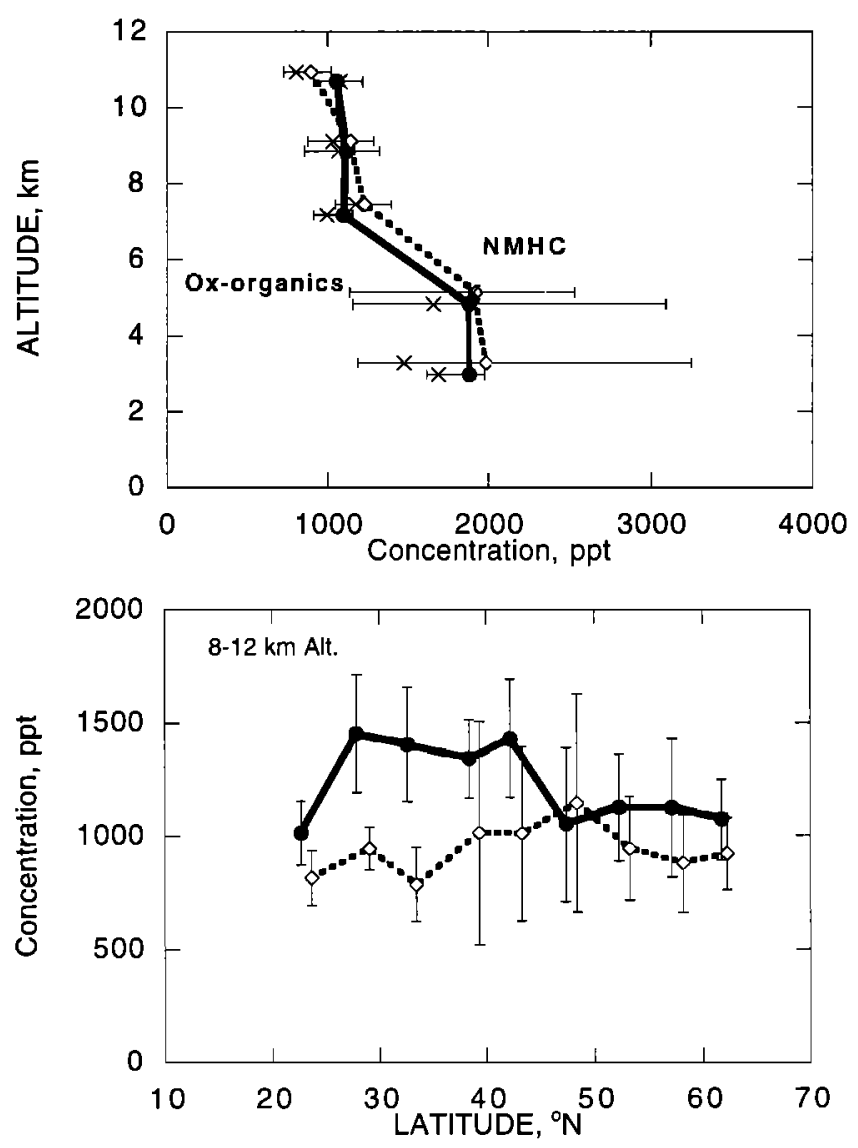

Figure 2. Tropospheric vertical and latitudinal distribution

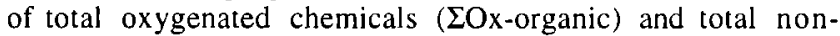
methane hydrocarbons ( $\Sigma \mathrm{NMHC}$ ) over the Atlantic as measured during SONEX. Layout is the same as in Figure 1.

$\left(45^{\circ}-65^{\circ} \mathrm{N}\right)$. The mean vertical distribution is based on $2 \mathrm{~km}$ altitude bins and mean, median, and percentiles are shown. The upper tropospheric latitudinal distribution is described by averaging data over the $8-12 \mathrm{~km}$ altitude bin. The actual data (1-min average) are also shown to give some idea of the distribution of sampling. It is evident that south of $40^{\circ} \mathrm{N}$ the sampling is much sparser than at higher latitudes. Higher $\mathrm{CO}$ mixing ratios in the lower troposphere are indicative of pervasive continental influences over the Atlantic. The Harvard 3-D model captures the observed distribution of $\mathrm{CO}$ quite well. It overestımates $\mathrm{O}_{3}$ and slightly underestimates $\mathrm{CO}$ in the UT. A possible reason for this may be the higher than normal tropopause levels observed during SONEX [Fuelberg et al., this issue].

Figure 2 provides a perspective on the abundance and distribution of total oxygenated chemicals ( $\Sigma O x$-organic) in relation to that of nonmethane hydrocarbons ( $\Sigma$ NMHC) measured during SONEX. These NMHC included a large number of alkanes, alkynes, alkenes, and aromatics. It is evident from Figure 2 that in the remote troposphere, oxygenated organics are collectively as abundant as NMHCs. Because many of them are easily photolyzed at tropospheric wavelengths, their influence on upper tropospherıc chemistry can be far greater than that of NMHC. As will be discussed in the following sectrons, the sources, sinks, and chemistry of these oxygenated molecules can differ greatly from each other. In many cases, significant biogenic sources appear to be present.
2.1.1. Organic nitrates. An onboard gas chromatograph (GC) operated by the NASA Ames group measured peroxyacetyl nitrate (PAN), peroxypropionyl nitrate (PPN), methyl nitrate $(\mathrm{MN})$, and ethyl/i-propyl nitrates in real time. The stable alkyl nitrates (methyl, ethyl, i-propyl, and 2-butyl) were also measured from the whole air samples collected by the University of California, Irvine group. Figure 3 shows a scatterplot of these measurements obtained by the two groups during the SONEX mission. Recognizing that the two techniques of sample collection are widely different, sampling times are not exactly identical, and mixing ratios are quite low, agreement between the onboard GC and canister sampled measurements is considered quite good. Statistical measures of ensemble averages indicated that these two data sets could be combined for all intents and purposes. PAN measurements were not duplicated on the DC-8, and it was also not measured on the POLINAT-2/Falcon, so no comparison is possible.

Figure 4 shows the tropospheric distribution of reactive organic nitrogen species along with that of $\mathrm{NO}_{y}$, a measure of the total available reactive nitrogen. Among this group of organic nitrates, PAN was the most abundant at $\approx 200 \mathrm{ppt}$ in the lower troposphere and $\approx 50 \mathrm{ppt}$ in the UT (Figures $4 \mathrm{a}$ and $4 \mathrm{~b}$ ). Typically PAN accounted for $10-30 \%$ of the available $\mathrm{NO}_{y}$. The higher concentrations in the lower troposphere are indicative of continental pollution influences over the Atlantic. Figure 4 also shows a comparison of modeled PAN and $\mathrm{NO}_{y}$ with SONEX observations with reasonable agreement. The
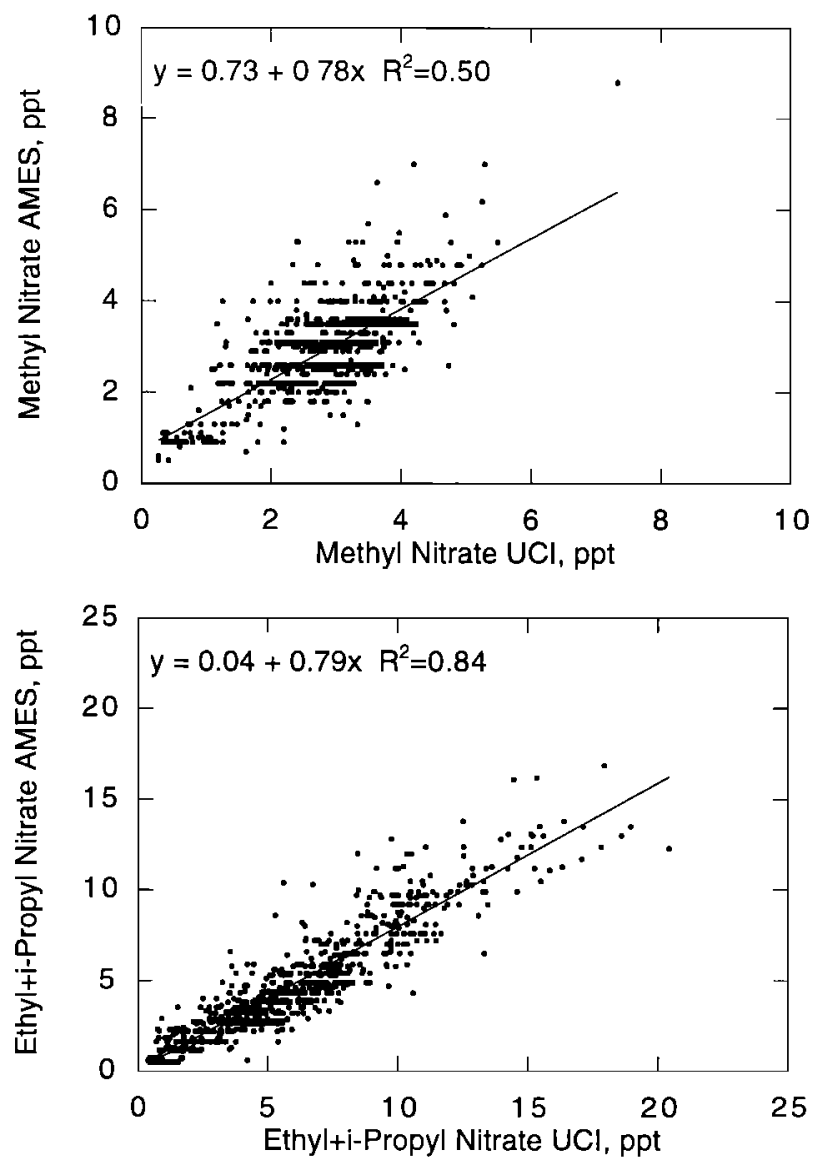

Figure 3. A comparıson of methyl nitrate and ethyl/i-propyl nitrate as measured aboard the DC-8 in real time by NASA Ames ( $y$ axis) and from the analysis of whole air samples by UCI ( $x$ axis) during SONEX. 

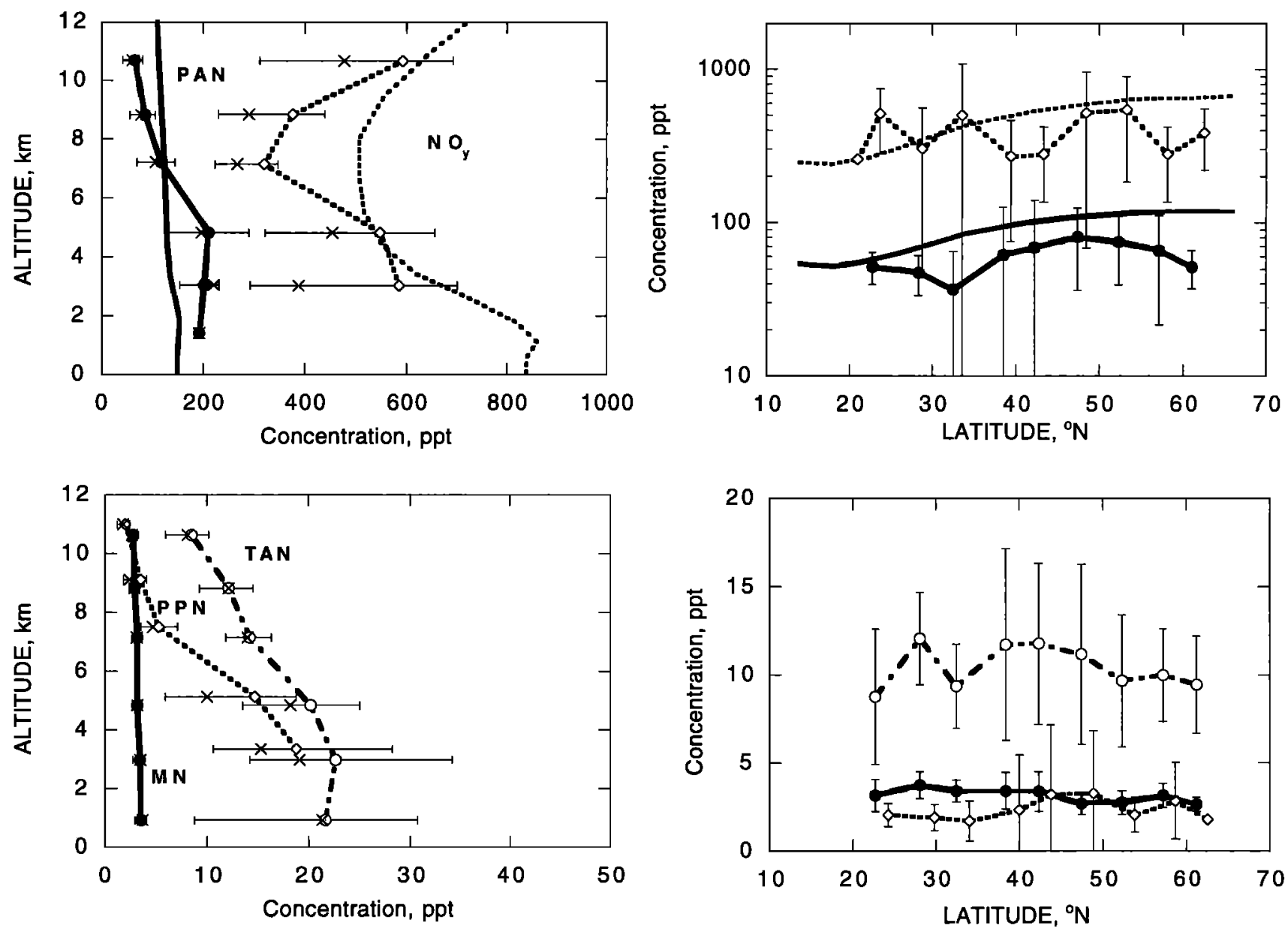

Figure 4. Tropospheric vertical and latitudinal distribution of select reactive nitrogen species measured during SONEX. Layout is the same as Figure in 1. PAN, peroxyacetyl nitrate; PPN, peroxypropionyl nitrate; MN, methyl nitrate; TAN, total alkyl nitrates; $\mathrm{NO}_{y}$ is the measured sum of total reactive nitrogen $(\Sigma \mathrm{N})$.

distribution of PPN (Figures $4 c$ and $4 d$ ) is similar to that of PAN, but its mixing ratios are significantly lower. This is largely due to the lesser abundance of PPN precursors as well as its somewhat shorter lifetime. Unlike PAN and PPN, methyl nitrate (MN) was nearly uniformly distributed in the troposphere (Figures $4 \mathrm{c}$ and $4 \mathrm{~d}$ ). It was clear that a large oceanic source, as observed in the tropical pacific (H. Singh, unpublished data, 1996), was not present in this region. Collectively, total alkyl nitrates (TAN) were present at relatively low concentrations with a distribution that was suggestive of surface, probably anthropogenic, sources (Figures $4 \mathrm{c}$ and $4 \mathrm{~d}$ ). Total alkyl nitrates on average accounted for less than $3 \%$ of reactive nitrogen $\left(\mathrm{NO}_{y}\right)$. All of these species (pernitrates and nitrates) are thermally and photochemically dissociatable and can act both as a source or a sink of the available free $\mathrm{NO}_{x}$ [Singh, 1987].

2.1.2. Carbonyls. Acetone and formaldehyde, two of the most important carbonyls in the atmosphere, were measured during SONEX. In recent years, acetone has been shown to be a globally abundant species that has the potential to both sequester reactive nitrogen as PAN and provide an upper tropospheric source of $\mathrm{HO}_{x}$ radicals [Singh et al., 1994, 1995; Arnold et al., 1997]. Similarly, formaldehyde is a well known product of methane oxidation and a major secondary source of
$\mathrm{HO}_{x}$ radicals [Crawford et al., 1999]. Acetone was measured on the DC- 8 with an onboard GC operated by the NASA Ames group and on the Falcon by the Max-Planck-Institute Heidelberg group who used a technique involving Chemical Ionization Mass Spectrometry (CIMS) [Arnold et al., 1997; Wohlfrom et al. 1999]. Both instruments quoted substantial error bars of $\pm 25 \%$ (GC) and $\pm 50 \%$ (CIMS). The CIMS instrument was not directly calibrated, and the reaction of product ions with water vapor was recognized as a potential source of error. The GC method collected a sample over a 150 -s period, while the CIMS instrument had a much faster response time (10 s). Figure 5 shows an example of the acetone distribution measured by the two aircraft when they were in the vicinity of each other during the two missions. The altitudes of the two aircraft are also shown, and the CIMS data have been averaged over the sampling time of the DC-8 instrument. During mission 5 (Figure 5a), the two instruments produced comparable data and saw acetone concentration decrease in the stratosphere (at $11 \mathrm{~km}$ ). However, the decline observed by the Falcon was less than that observed by the DC-8. Similarly, during mission 7 , the DC- 8 measurement is some $30 \%$ lower than the CIMS measurement. These results are within the quoted error bars of these instruments. Figure 6 shows the vertical and latitudinal distribution of acetone in the troposphere based only 

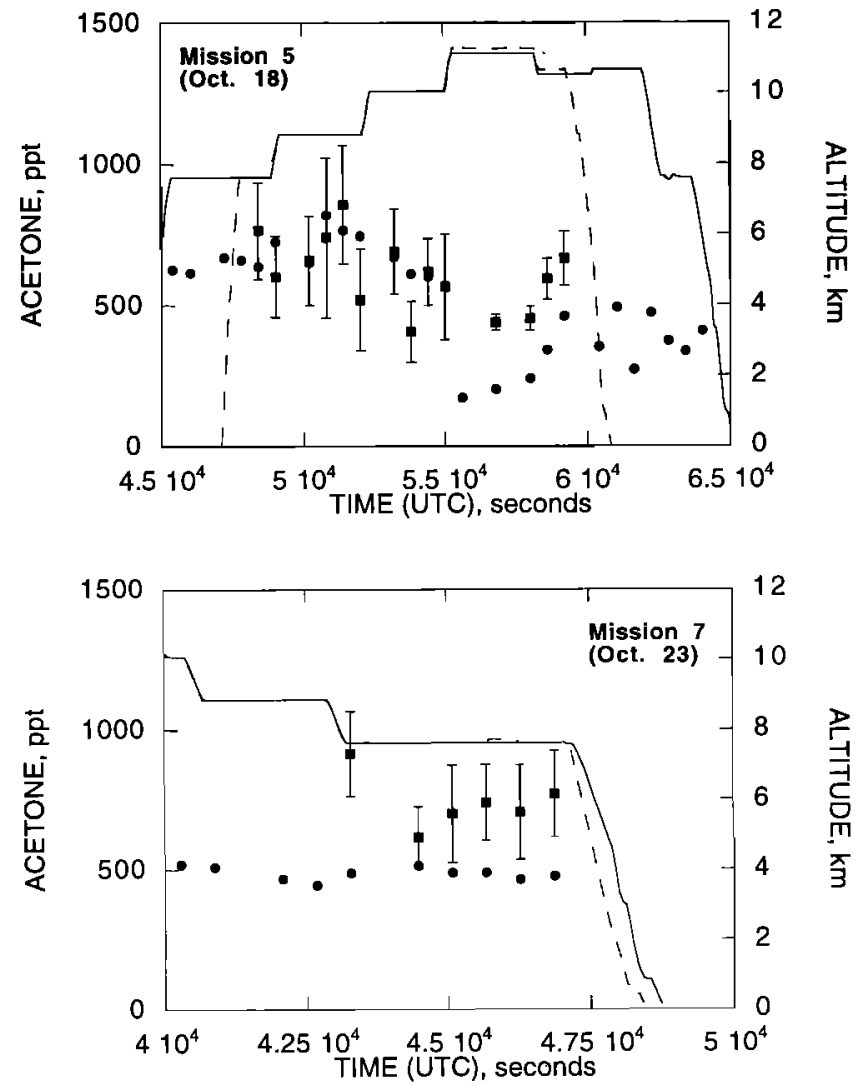

Figure 5. A comparison of acetone as measured on the DC-8 (solid circles) and the Falcon (solid squares) using two independent techniques. The altitude profile DC-8 (solid line) and Falcon-20 (dashed line) is shown.

on the GC data collected on the DC-8. A slight decline in the upper tropospheric abundance of acetone toward the subtropics was observed. This is expected due to the greater loss of acetone due to photolysis and has been previously observed over the Pacific [Singh et al., 1995]. Although acetone measure- ment accuracy needs to improve in the future, it is evident that substantial concentrations of acetone are present in the troposphere. The role of acetone as a source of $\mathrm{HO}_{x}$ during SONEX has been discussed by Jaeglé et al. [this issue].

Global sources of acetone are not well known although a first emissions inventory with a $40-60 \mathrm{Tg} \mathrm{yr}^{-1}$ source was presented by Singh et al. [1994]. Here we shall update this emissions data based on new information. In recent years, a number of previously suggested biogenic pathways have been confirmed, and new ones have been identified. Pastures have been found to emit significant quantities of acetone [Kirstine et al., 1998], and elevated levels of acetone in rural forested areas are routinely observed [Goldan et al., 1995; Reimer et al., 1998; Fall, 1999; Lamanna and Goldstein, 1999]. Singh et al. [1994] deduced that the $15( \pm 10) \%$ acetone yield from $\alpha$ pinene/OH reaction, as reported by $\mathrm{C}$. $\mathrm{Gu}$ and co-workers (unpublished report, 1984), would constitute an $\approx 6 \mathrm{Tg} \mathrm{yr}^{-1}$ source of acetone. More recently, $\alpha$ - and $\beta$-pinenes have been confirmed to have a $8-15 \%$ acetone yield upon $\mathrm{OH}$ reaction, and acetone yields from many other monoterpenes from $\mathrm{OH} / \mathrm{O}_{3}$ reactions have been determined [Reissell et al., 1999]. Similarly, $\mathrm{OH}$ oxidation of 2-methyl-3-buten-2-ol, another terrestrial biogenic product, results in a 50-60\% yield of acetone [Ferronato et al., 1998; Alvardo et al., 1999]. Recent best estimates of the global emissions of monoterpenes and 2methyl-3-buten-2-ol are 130-150 $\mathrm{Tg} \mathrm{yr}^{-1}$ and 3-6 $\mathrm{Tg} \mathrm{yr}^{-1}$, respectively [Guenther et al., 1995; 1999; Harley et al., 1998]. On the basis of these emission rates and the avalable kınetic information, we calculate that a secondary biogenic source of $\approx 11 \mathrm{Tg} \mathrm{yr}^{-1}$ of acetone is present. This is likely to be a lower limit as $1 t$ only considers the first stages of chemical reactions, and additional secondary formation may occur. It is also likely that the day/night difference observed in the mixing rat10 of acetone in forested areas [Goldan et al., 1995] is in part due to this secondary source. Biomass burning source of acetone has also been determined (3-10 $\mathrm{Tg} \mathrm{yr}^{-1}$ ) from direct atmospheric measurements and laboratory experiments [Singh et al., 1994; Holzinger et al., 1999]. Acetone sources from dead plant matter via abiological processes have been estimated to be 6-8 $\mathrm{Tg} \mathrm{yr}^{-1}$ [Warneke et al., 1999]. Human breath contains

Table 1. An Estimate of the Global Source Inventory of Acetone

\begin{tabular}{|c|c|c|}
\hline Source Type & $\begin{array}{c}\text { Global Annual } \\
\text { Emissions, } \mathrm{Tg}_{\mathrm{yr}}^{-1}\end{array}$ & Comments ${ }^{*}$ \\
\hline Prımary anthropogenic & $2(1-3)$ & $=95 \% \mathrm{NH}$ \\
\hline Pnmary biogenic & $15(10-20)$ & not well quantified \\
\hline \multicolumn{3}{|c|}{ Secondary anthropogenic and biogenic } \\
\hline Propane oxidation & $15(10-20)$ & $\approx 80 \% \mathrm{NH}$ \\
\hline i-Butane/1-pentane oxidation & $1(1-2)$ & $\approx 80 \% \mathrm{NH}$ \\
\hline i-Butene/1-pentene oxıdation & $1(1-2)$ & $\approx 80 \% \mathrm{NH}$ \\
\hline $\begin{array}{l}\text { Monoterpene/methyl butenol } \\
\text { Oxidation }^{+}\end{array}$ & $11(7-15)$ & \\
\hline Dead/decaying plant matter & $6(4-8)$ & \\
\hline Biomass burning & $5(3-10)$ & $\approx 70 \% \mathrm{SH}$ \\
\hline Total source strength & $56(37-80)$ & \\
\hline Total sink strength & $40-60$ & $\begin{array}{l}\text { removal via } \mathrm{hv}, \mathrm{OH} \text {, and slow } \\
\text { deposition }\end{array}$ \\
\hline
\end{tabular}

\footnotetext{
*NH, northern hemisphere, SH, southern hemisphere

${ }^{+}$These terrestrial bogenic hydrocarbons are known to have large yields of acetone upon $\mathrm{OH}$ and $\mathrm{O}_{3}$ oxıdation (see text)
} 

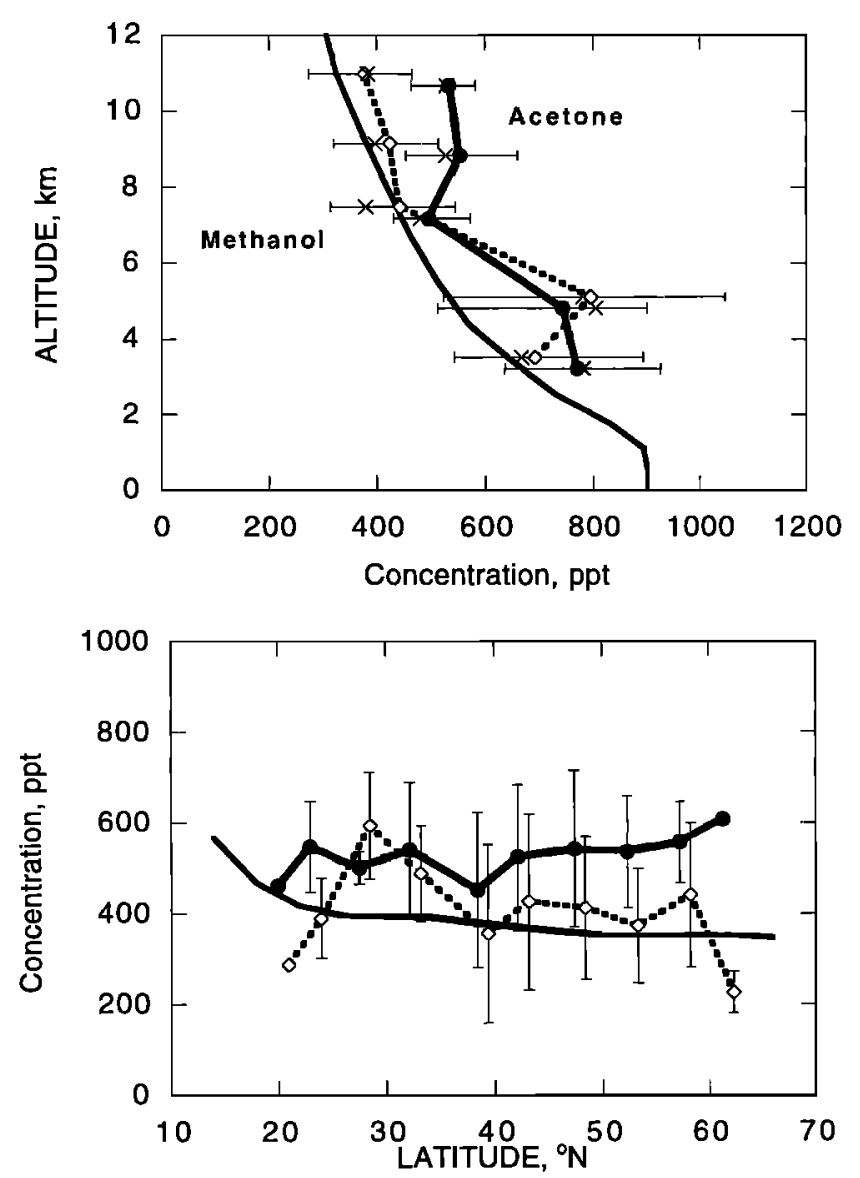

Figure 6. Tropospheric vertical and latitudinal distribution of acetone and methanol during SONEX. Layout is the same as in Figure 1.

relatively high concentrations of acetone $\left(10^{3}-10^{4} \mathrm{ppb}\right)$, but this is only a significant source in indoor environments [Lindinger et al., 1998]. Table 1 provides an updated source inventory of acetone with a global source of $56 \mathrm{Tg} \mathrm{yr}^{-1}$ which

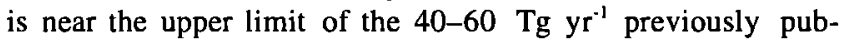
lished by Singh et al. [1994].

Unlike acetone, formaldehyde has an extremely short life in the atmosphere (a few hours), and its source is expected to be largely due to hydrocarbon oxidation. Although direct emissions of formaldehyde from automobile exhaust and biomass burning are known to exist, these sources are small $(<5 \%)$ in comparison with the $\approx 10^{3} \mathrm{Tg} \mathrm{yr}^{-1}$ of HCHO that can be globally produced from $\mathrm{CH}_{4}$ oxidation alone. We note that a substantial fraction of the $\mathrm{HCHO}$ data $(42 \%$ within $4-8 \mathrm{~km}$ and $52 \%$ within $8-12 \mathrm{~km}$ ) were below the limit of detection (LOD). Here we have used $0.5 \mathrm{LOD}$ as the mixing ratio for these instances. When 0.25 LOD was used for sensitivity purposes, mean concentrations in the UT were further reduced by 5-10 ppt. It is evident from Figure 7 that substantial concentrations of $\mathrm{HCHO}$ are present in the troposphere. Figure 7 also shows that the observed mean HCHO concentrations are in reasonable agreement with those predicted by the Harvard model. During typical SONEX conditions, we calculate that acetone photolysis may be responsible for 5-7 ppt of $\mathrm{HCHO}$ in the UT. It should be noted that point models are unable to reconcile measured concentrations of $\mathrm{HCHO}$ which exceeded $70 \mathrm{ppt}$ and should be the most reliable [e.g., Jaeglé et al., this issue].
There is a weak linear relationship $\left(R^{2}=0.3\right)$ between methanol and formaldehyde concentrations for all cases when data are above LOD. This relationship might be used to suggest that methanol is a potential source of formaldehyde or conversely a potential interferent in its measurement. At this point, neither the possibility of additional sources for HCHO nor the potential for measurement errors can be completely ruled out. HCHO is a key intermediate of atmospheric oxidation whose atmospheric fate cannot be fully reconciled until more sensitive and accurate measurements are possible.

2.1.3. Peroxides. Peroxides are secondary products of atmospheric oxidation $\left(\mathrm{RO}_{2}+\mathrm{HO}_{2} \rightarrow \mathrm{ROOH}+\mathrm{O}_{2}\right)$, and their direct emissions are extremely small in comparison [Heikes et al., 1996; Lee et al., 1999]. The organic methylhydroperoxide $\left(\mathrm{CH}_{3} \mathrm{OOH}\right)$ is much less soluble than $\mathrm{H}_{2} \mathrm{O}_{2}$ and can be transported via moist cloud convection into the UT thus providing a local source of $\mathrm{HO}_{x}$ [Jaeglé et al., 1997; Crawford et al., 1999]. Both hydrogen peroxide and methylhydroperoxide were measured during SONEX. A substantial fraction of the $\mathrm{CH}_{3} \mathrm{OOH}$ data (28\% within $4-8 \mathrm{~km}$ and $44 \%$ within $8-12 \mathrm{~km}$ ) were below the limit of detection. Here we have used $0.5 \mathrm{LOD}$ as the mixing ratio for these. When 0.25 LOD was used for sensitivity purposes, the mean concentrations were minimally altered $(<5 \mathrm{ppt})$. Figure 7 shows the vertical and UT latitudinal distribution of $\mathrm{CH}_{3} \mathrm{OOH}$. The atmospheric abundance of $\mathrm{CH}_{3} \mathrm{OOH}$ is comparable to that of $\mathrm{HCHO}$. Even though the model appears to be in better agreement with observations in the UT, this must be considered fortuitous. Throughout the
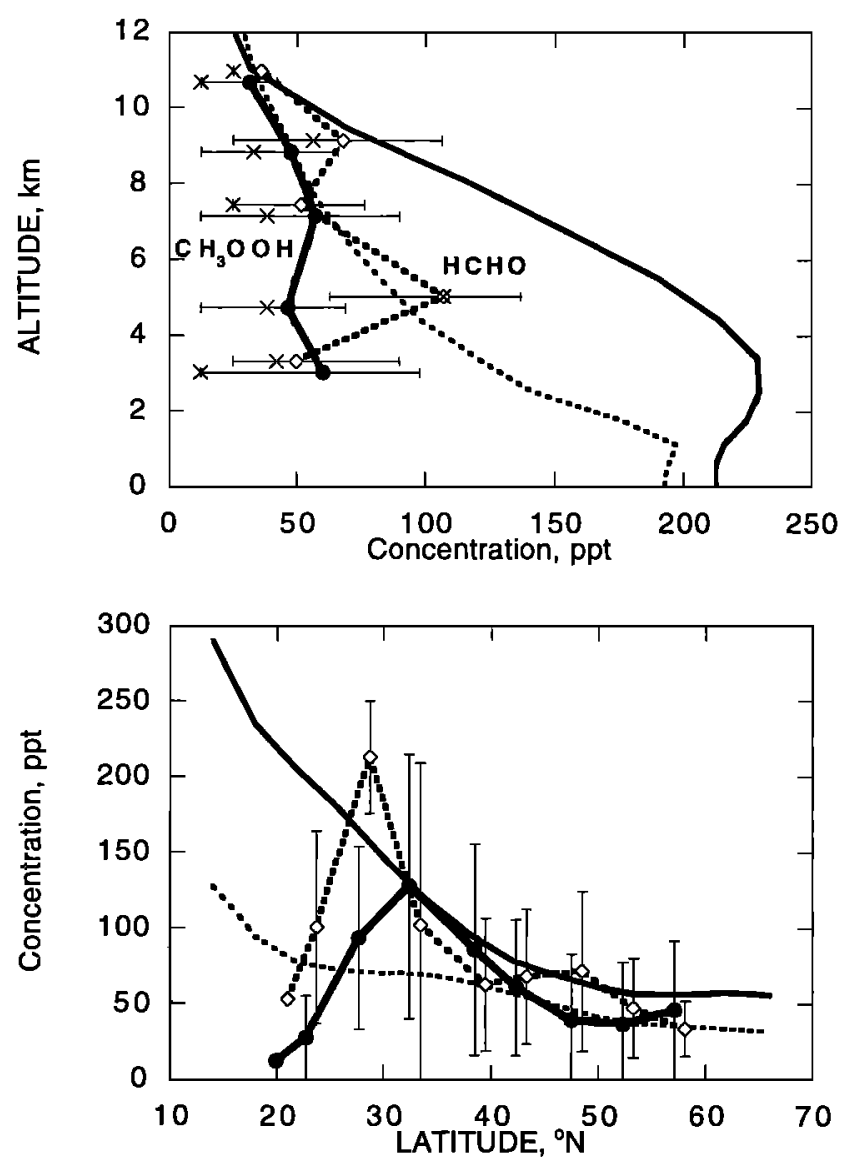

Figure 7. Tropospheric vertical and latitudinal distribution of formaldehyde and methylhydroperoxide during SONEX. Layout is the same as Figure in 1. 

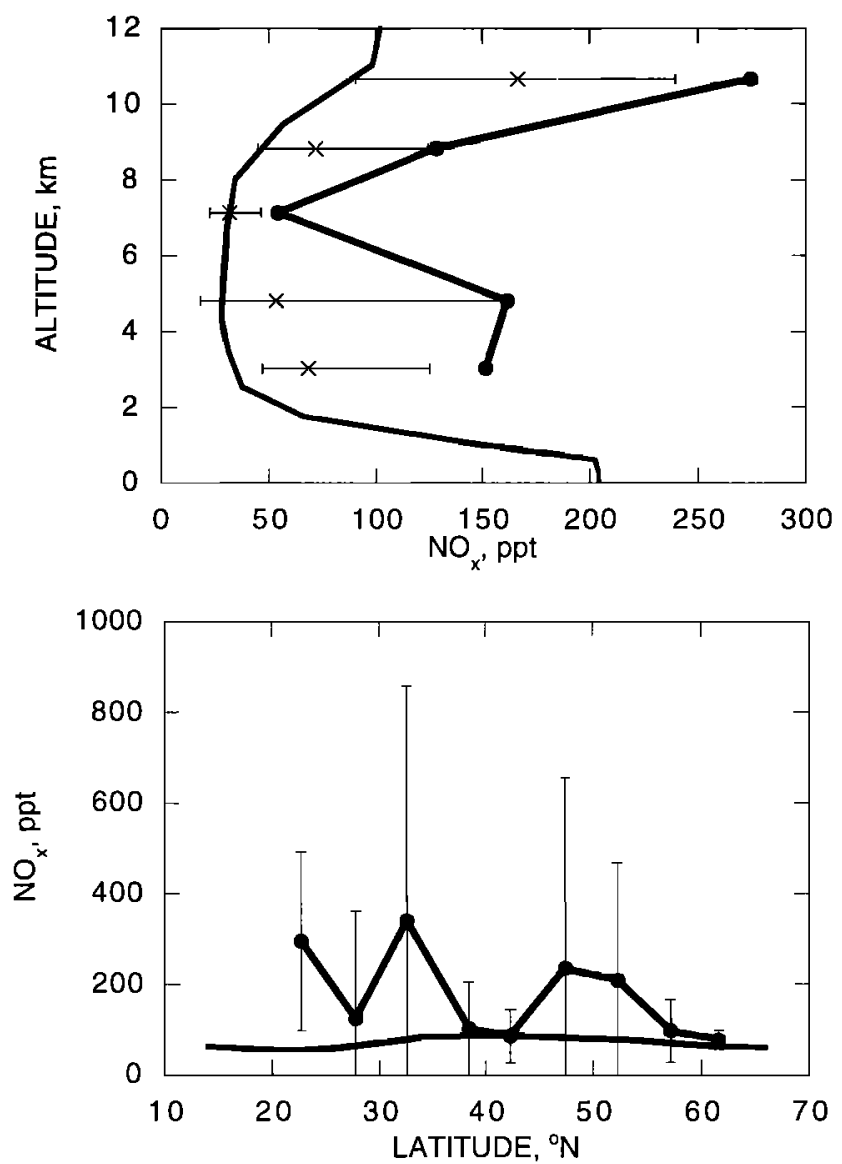

Figure 8. Tropospheric vertical and latitudinal distribution of $\mathrm{NO}_{x}$ during SONEX. Layout is the same as Figure in 1 .

troposphere, the simulation of $\mathrm{CH}_{3} \mathrm{OOH}$ is a substantial overprediction of observations. This overprediction of $\mathrm{CH}_{3} \mathrm{OOH}$ is contrary to previous findings from the South Atlantic [Jacob et al., 1996]. We believe a major reason for this is due to the fact that the observed $\mathrm{NO}_{x}$ is nearly a factor of 2 larger than the model prediction throughout the troposphere (Figure 8), thus allowing for a much faster rate of $\mathrm{CH}_{3} \mathrm{OOH}$ formation in the model. Uncertanties in the $\mathrm{CH}_{3} \mathrm{O}_{2}+\mathrm{HO}_{2}$ rate constant [Demore et al., 1997] also contribute to this disagreement. $\mathrm{CH}_{3} \mathrm{OOH}$ is a key intermediate of secondary $\mathrm{HO}_{x}$ production whose atmospheric fate cannot be fully reconciled with present knowledge. The need for more sensitive measurements in the UT is clearly indicated.

2.1.4. Alcohols. Both methanol and ethanol were measured during SONEX. Significant concentrations of methanol (400-800 ppt) were present in the Atlantic troposphere at all times (Figure 6). Ethanol concentrations were often undetectable and nearly always below $50 \mathrm{ppt}$. The gas phase oxidation of methanol via $\mathrm{OH}$ leads to formaldehyde formation $\left(\mathrm{CH}_{3} \mathrm{OH}+\mathrm{OH}+\left(\mathrm{O}_{2}\right) \rightarrow \mathrm{CH}_{2} \mathrm{O}+\mathrm{HO}_{2}+\mathrm{H}_{2} \mathrm{O}\right)$, but this process is too slow in the UT to be a significant source of formaldehyde and free radicals [Singh et al., 1995]. Methanol was less abundant in the UT relative to acetone despite its longer lifetıme in the UT due to slow $\mathrm{OH}$ reactivity. Methanol is preferentially partitioned in the gas phase even at very low temperatures $\left(K_{H}=10^{3} M \mathrm{~atm}^{-1}\right.$ at $273^{\circ} \mathrm{K}$ in water). It can be argued that the greater relative decline of methanol compared to acetone in the UT is due to the presence of secondary sources of acetone throughout the troposphere. The presence of unknown, possibly heterogeneous, processes that could provide effective sinks for methanol also cannot be ruled out. A weak linear correlation $\left(R^{2}=0.4\right)$ of methanol mixing ratios with those of acetone and $\mathrm{CO}$ (molecules with comparable lifetimes) was observed suggesting some commonalty of sources. A similar relationshıp $\left(R^{2}=0.3\right)$ between methanol and formaldehyde (short-lived) may be used to suggest that methanol is a potential source of atmospheric formaldehyde or conversely a potential interferent in its measurement.

A source inventory for methanol does not exist, but based on removal by $\mathrm{OH}$ and slow deposition $\left(\approx 0.1 \mathrm{~cm} \mathrm{~s}^{-1}\right)$, it has been calculated that a global methanol source of 40-50 $\mathrm{Tg} \mathrm{yr}^{-1}$ must exist. Recent studies of emissions from plants and leaves, and the presence of high concentrations of methanol in forested and rural areas point to a sizable brogenic source [MacDonald and Fall, 1993; Goldan et al, 1995; Kirstine et al., 1998; Reimer et al., 1998; Fall, 1999; Lamanna and Goldstein, 1999]. The measured biogenic emission rates are sufficiently large for a methanol source of $>100 \mathrm{Tg} \mathrm{yr}^{-1}$ [Guenther et al., 1995, 1999]. Large methanol sources from dead plant matter via abılogical processes have been reported to be $18-40$ Tg $\mathrm{yr}^{\prime}$ [Warneke et al., 1999]. Additional smaller sources from biomass burnıng (3-17 $\mathrm{Tg} \mathrm{yr}^{-1}$ ) and direct anthropogenic emissions (2-4 $\mathrm{Tg} \mathrm{yr}^{1}$ ) are present [Singh et al., 1995; Holzinger et al., 1999; Yokelson et al., 1999]. On the basis of the globel model of Lawrence et al. [1999], secondary source from

Table 2. An Estimate of the Global Source Inventory of Methanol

\begin{tabular}{|c|c|c|}
\hline Source Type & $\begin{array}{l}\text { Global Annual } \\
\text { Emissions, Tg yr }{ }^{-1}\end{array}$ & Comments \\
\hline Primary anthropogenic & $3(2-4)$ & $\approx 95 \% \mathrm{NH}$ \\
\hline Primary biogenic & $75(50-125)$ & not well quantıfied \\
\hline Methane oxidation & $18(12-24)$ & 3-D inodel estimate \\
\hline Dead/decaying plant matter & $20(10-40)$ & \\
\hline B1omass burning & $6(3-17)$ & $\approx 70 \% \mathrm{SH}$ \\
\hline Oceanic source & $? ? ?$ & likely source \\
\hline Total source strength & $122(75-210)$ & \\
\hline Total sink strength & $40-50$ & $\begin{array}{l}\text { removal via } \mathrm{OH} \text { and } \\
\text { slow deposition }\end{array}$ \\
\hline
\end{tabular}



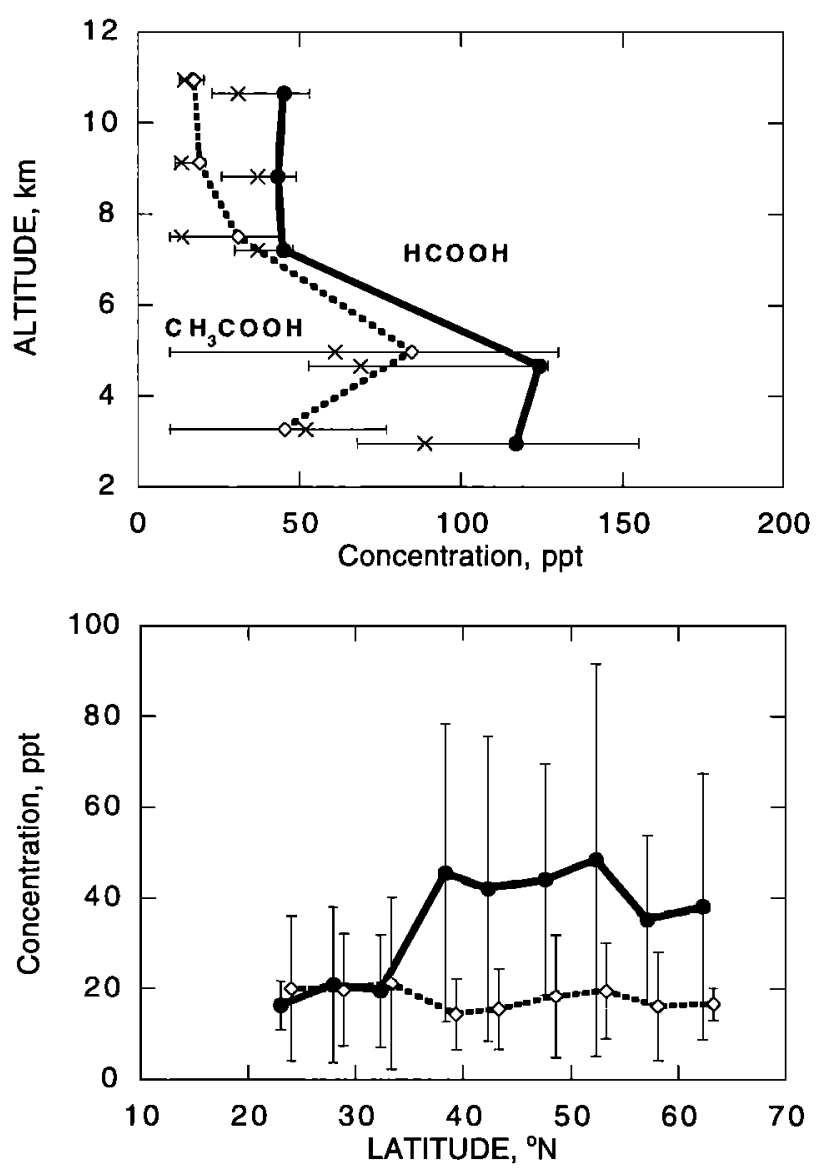

Figure 9. Tropospheric vertical and latitudinal distribution of acetic acid and formic acid during SONEX. Layout is the same as Figure in 1.

$\mathrm{CH}_{4} / \mathrm{NMHC}$ oxidation pathways $\left(2 \mathrm{CH}_{3} \mathrm{O}_{2} \rightarrow \mathrm{CH}_{3} \mathrm{OH}+\mathrm{CH}_{2} \mathrm{O}+\right.$

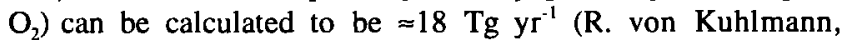
Max-Planck-Institute for Chemistry, private communication, 1999). Although $\mathrm{CH}_{3} \mathrm{OH}$ is easily synthesized in seawater from the hydrolysis of methyl halides, no estimate of its oceanic source is presently available. Table 2 summarizes a first inventory of the global sources $\left(\approx 122 \mathrm{Tg} \mathrm{yr}^{-1}\right)$ of methanol indicating that its sources far exceed its known sinks. If this estimate of the global methanol source is found to be correct, then removal mechanisms other than $\mathrm{OH}$ oxidation (and slow deposition) must play an important role. In the boundary layer, aerosol media containing $\mathrm{OH}^{-}, \mathrm{Cl}^{-}$, and $\mathrm{SO}_{4}{ }^{--}$could react with methanol to form complex products. In the middle and UT, methanol may also react in clouds to oxidize into organic acids or react with $\mathrm{H}_{2} \mathrm{SO}_{4}$ in cloud droplets to form methanesulphonic acid [Murphy et al., 1998]. Suffice it to say that methanol is a globally abundant organic species with limited atmospheric data and poorly understood sources and removal processes.

2.1.5. Organic acids. Formic and acetic acids are ubıquitous trace gases in the atmosphere and contribute a large fraction of the free acidity in precipitation in remote areas [Keene and Galloway, 1988]. During SONEX, formic acid was present in concentrations of $\approx 45 \mathrm{ppt}$ in the UT and $\approx 120 \mathrm{ppt}$ in the lower troposphere (Figure 9). The mean abundance of acetic acid was less than half that of formic acid. Unlike formic acid, a large fraction of the acetic acid data (50\% between 4-8

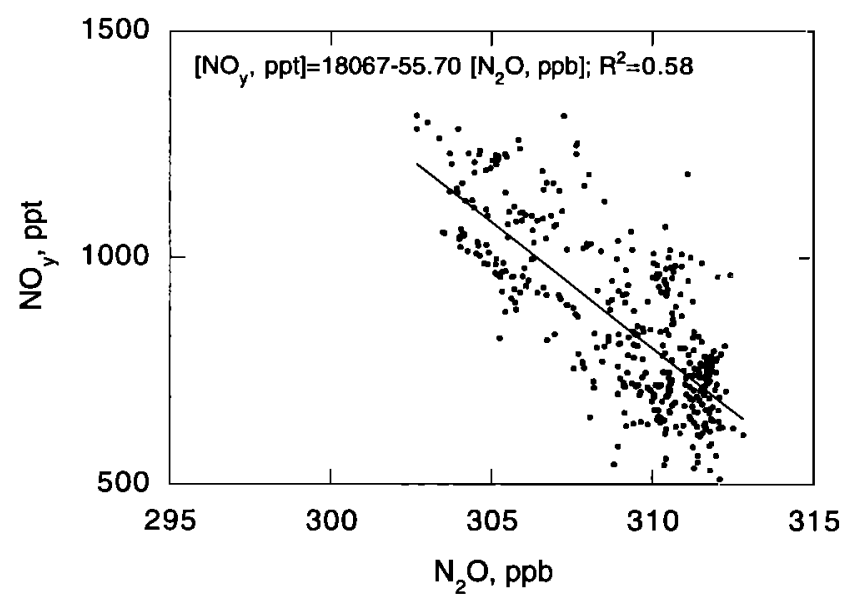

Figure 10. The relationship between $\mathrm{NO}_{y}$ and $\mathrm{N}_{2} \mathrm{O}$ in the "lowermost" stratosphere. The stratosphere is defined by $\mathrm{O}_{3}>100 \mathrm{ppb}$ and $\mathrm{Z}>6 \mathrm{~km}$.

$\mathrm{km}$ and $85 \%$ between $8-12 \mathrm{~km}$ ) were below the limit of detection (LOD). As stated earlier, in Figure 9 we have used LOD data at a value of 0.5 LOD. The UT acetic acid abundance is clearly highly influenced by the treatment of LOD data. When 0.25 LOD was used for sensitivity purposes, the UT concentrations were reduced by about $10 \mathrm{ppt}$ with no perceptible change

Table 3. Mixing Ratios of Selected Trace Constituents in the "Lowermost" Stratosphere $\left(\mathrm{O}_{3}>100 \mathrm{ppb} ; \mathrm{Z}>6 \mathrm{~km}\right)$ During SONEX

\begin{tabular}{|c|c|}
\hline Trace Chemicals & $\begin{array}{c}\text { Mixing Ratios } \\
\{\text { Mean } \pm \sigma(\text { Median, } n)\}\end{array}$ \\
\hline $\mathrm{O}_{3}, \mathrm{ppb}$ & $191 \pm 82(165,685)$ \\
\hline $\mathrm{N}_{2} \mathrm{O}, \mathrm{ppb}$ & $309 \pm 3(310,476)$ \\
\hline $\mathrm{H}_{2} \mathrm{O}$, ppm & $46 \pm 26(40,614)^{*}$ \\
\hline $\mathrm{CH}_{4}, \mathrm{ppb}$ & $1722 \pm 20(1728,582)$ \\
\hline $\mathrm{CO}, \mathrm{ppb}$ & $48 \pm 14(48,581)$ \\
\hline $\mathrm{NO}_{\gamma}, \mathrm{ppt}$ & $874 \pm 194(881,592)$ \\
\hline NO, ppt & $67 \pm 58(51,586)$ \\
\hline $\mathrm{NO}_{x}, \mathrm{ppt}$ & $136 \pm 83(133,477)$ \\
\hline $\mathrm{HNO}_{3}, \mathrm{ppt}$ & $649 \pm 255(628,178)$ \\
\hline PAN, ppt & $61 \pm 29(54,115)$ \\
\hline PPN, ppt & $1.7 \pm 1.3(1,53)^{+}$ \\
\hline $\mathrm{CH}_{3} \mathrm{ONO}_{2}, \mathrm{ppt}$ & $1.3 \pm 06(1.3,218)$ \\
\hline $\mathrm{C}_{2} \mathrm{H}_{5} \mathrm{ONO}_{2}, \mathrm{ppt}$ & $1.1 \pm 0.6(1.0,220)$ \\
\hline $\mathrm{i}-\mathrm{C}_{3} \mathrm{H}_{7} \mathrm{ONO}{ }_{2}, \mathrm{ppt}$ & $0.7 \pm 0.8(0.4,220)$ \\
\hline HCHO, ppt & $31 \pm 19(25,78)^{\dagger}$ \\
\hline Acetone, ppt & $336 \pm 225(296,55)$ \\
\hline $\mathrm{CH}_{3} \mathrm{OH}, \mathrm{ppt}$ & $104 \pm 102(71,55)$ \\
\hline $\mathrm{CH}_{3} \mathrm{OOH}, \mathrm{ppt}$ & $16 \pm 14(12,232)^{\dagger}$ \\
\hline $\mathrm{H}_{2} \mathrm{O}_{2}, \mathrm{ppt}$ & $31 \pm 24(26,232)$ \\
\hline $\mathrm{CH}_{3} \mathrm{COOH}, \mathrm{ppt}$ & $23 \pm 10(2 \mathrm{l}, 172)^{\dagger}$ \\
\hline $\mathrm{HCOOH}, \mathrm{ppt}$ & $39 \pm 27(30,178)^{\dagger}$ \\
\hline $\mathrm{C}_{2} \mathrm{H}_{6}, \mathrm{ppt}$ & $380 \pm 160(381,220)$ \\
\hline $\mathrm{C}_{3} \mathrm{H}_{8}, \mathrm{ppt}$ & $38 \pm 44(24,220)$ \\
\hline $\mathrm{C}_{2} \mathrm{H}_{2}, \mathrm{ppt}$ & $43 \pm 26(37,220)$ \\
\hline $\mathrm{C}_{2} \mathrm{H}_{4}, \mathrm{ppt}$ & $2 \pm 4(1,97)^{\dagger}$ \\
\hline $\mathrm{C}_{6} \mathrm{H}_{6}, \mathrm{ppt}$ & $4 \pm 5(2,178)$ \\
\hline 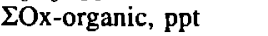 & $563 \pm 262(507,40)$ \\
\hline ENMHC, ppt & $476 \pm 245(220,449)$ \\
\hline $\mathrm{CN}$-fine, number $\mathrm{cm}^{-3}$ & $1037 \pm 659(896,685)$ \\
\hline
\end{tabular}

"An instrumental offset $(\approx 10 \mathrm{ppm})$ has been detected. Actual concentrations are lower.

${ }^{\dagger}$ Generally near the limit of detection. 

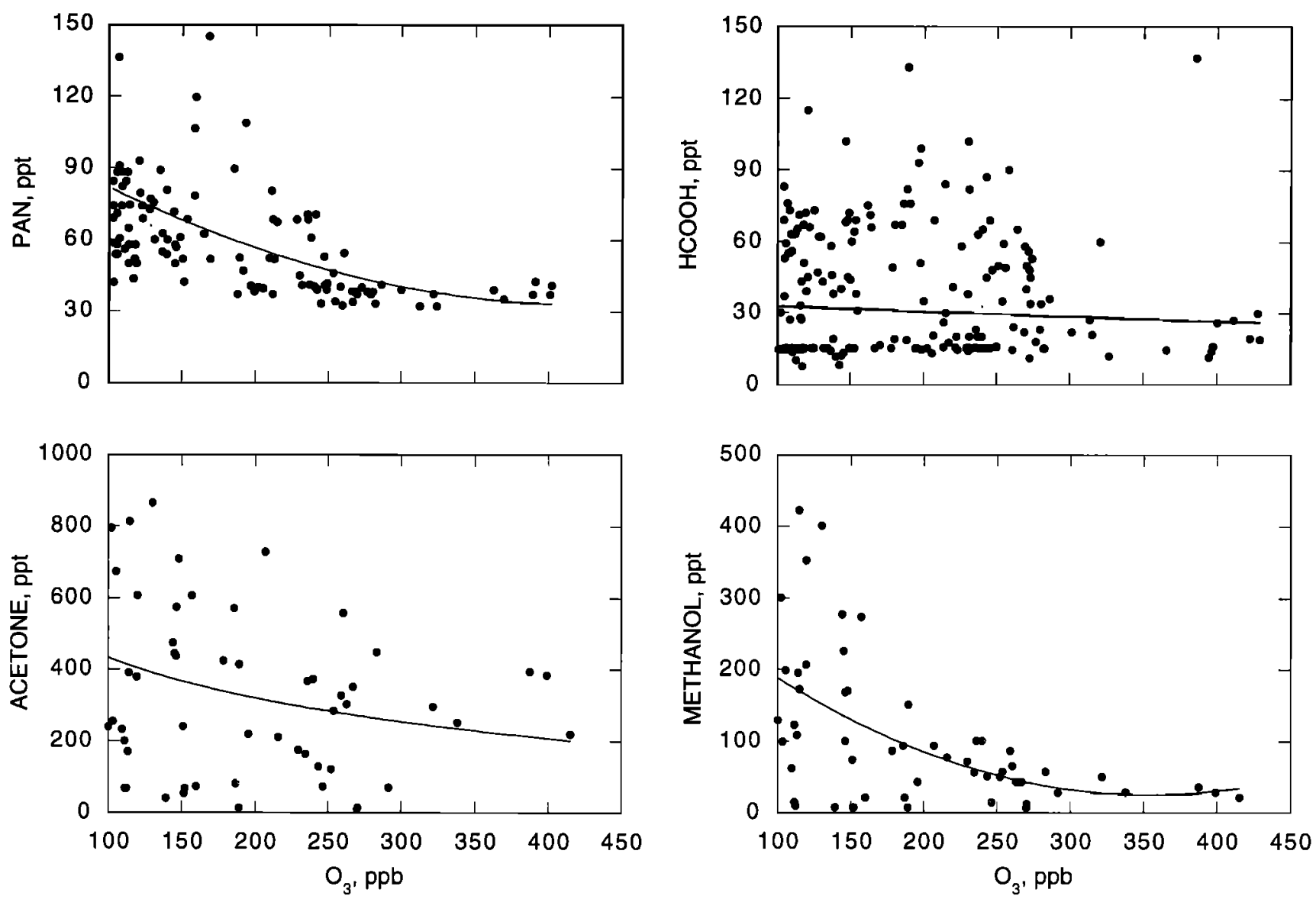

Figure 11. Mixing ratios of selected oxygenated species as a function of $\mathrm{O}_{3}$ in the "lowermost" stratosphere.

below $7 \mathrm{~km}$. Primary emissions from terrestrial vegetation and from combustion of fuel and biomass, and secondary formation from gas phase and liquid reactions are known to be present [Talbot et al., 1990; Fall; 1999; Yokelson et al., 1999]. Although acetic acid could react with $\mathrm{OH}$ radicals to form $\mathrm{HCHO}\left(\mathrm{CH}_{3} \mathrm{COOH}+\mathrm{OH} \rightarrow \mathrm{CH}_{3} \mathrm{O}_{2} \rightarrow \mathrm{CH}_{3} \mathrm{OOH}\right.$ and $\mathrm{HCHO}$ ), the process is quite slow, and this is at best a minor source of $\mathrm{HO}_{x}$ radicals. In most cases, organic acids are removed from the atmosphere by wet and dry deposition processes, and their chemistry is at best highly uncertain [Talbot et al., 1990, 1995; Jacob et al., 1996]. An accurate enough source inventory for these organic acids is not currently available to model their global distribution.

\subsection{Stratospheric Distributions}

The stratosphere was frequently penetrated during SONEX. Chemical indicators of the stratospheric air suggested that these instances represented the "lowermost" stratosphere $\left(\mathrm{O}_{3}<450 \mathrm{ppb} ; \mathrm{N}_{2} \mathrm{O}>300 \mathrm{ppb}\right)$. Figure 10 shows the $\mathrm{NO}_{y}$ and $\mathrm{N}_{2} \mathrm{O}$ relationship for the stratospheric data set defined by $\mathrm{O}_{3}>100 \mathrm{ppb}$ and $\mathrm{Z}>6 \mathrm{~km}$. There is substantial scatter largely associated with the fact that sampled air is a mix of tropospheric and stratospheric influences. The slope of this line ( $\left[\mathrm{NO}_{y}, \mathrm{ppt}\right]=18,067-55.7\left[\mathrm{~N}_{2} \mathrm{O}, \mathrm{ppb}\right] ; R^{2}=0.6$ ) is comparable to but somewhat less steep than previously reported data [Singh et al., 1997; Keim et al., 1997]. $\mathrm{N}_{2} \mathrm{O}$ correlation with $\mathrm{HNO}_{3}\left(\left[\mathrm{HNO}_{3}, \mathrm{ppt}\right]=25,431-80.2\left[\mathrm{~N}_{2} \mathrm{O}, \mathrm{ppb}\right] ; R^{2}=0.6\right), \mathrm{O}_{3}$ $\left(\left[\mathrm{O}_{3}, \mathrm{ppb}\right]=6924-21.9\left[\mathrm{~N}_{2} \mathrm{O}, \mathrm{ppb}\right] ; R^{2}=0.9\right)$, and $\mathrm{CH}_{4}\left(\left[\mathrm{CH}_{4}\right.\right.$,
$\mathrm{ppb}]=-447+7.0\left[\mathrm{~N}_{2} \mathrm{O}, \mathrm{ppb}\right] ; R^{2}=0.9$ ) are in good agreement with previously reported results from the Pacific [e.g., Singh et al., 1997].

In nearly all cases, mixing ratios of oxygenated organic species declined rapidly above the tropopause. Deeper into the stratosphere, mixing ratios of acids, peroxides, formaldehyde, and methanol were extremely low and near the limit of detection as $\mathrm{O}_{3}$ approached $400 \mathrm{ppb}$. Figure 11 shows the distribution of some selected oxygenates as a function of $\mathrm{O}_{3}$. PAN and acetone declined at a slower rate than methanol and other NMHC (e.g., $\mathrm{C}_{2} \mathrm{H}_{6}$ ). In this region, which is believed to have $\approx 10^{3}$ molecules $\mathrm{cm}^{-3}$ of $\mathrm{Cl}$ atoms, $\mathrm{Cl}$ chemistry instead of $\mathrm{OH}$ dominates the oxidation process. PAN, however, reacts negligibly slowly with $\mathrm{Cl}$ atoms and may have a potential local source resulting from $\mathrm{C}_{3} \mathrm{H}_{8} / \mathrm{C}_{2} \mathrm{H}_{6}-\mathrm{Cl}$ and acetone photochemistry [Demore et al., 1997]. Acetone itself can also be produced from $\mathrm{C}_{3} \mathrm{H}_{8}-\mathrm{Cl}$ oxidation in this region. The slower net loss rate of acetone compared to methanol is evident from the fact that the acetone to methanol ratio in the stratosphere increased from about 2 to 8 as $\mathrm{O}_{3}$ increased from 100 to $400 \mathrm{ppb}$. There is some indication, based on extremely sparse data, that acetic acid increased in the LS from $40 \mathrm{ppt}\left(\mathrm{O}_{3} \approx 100-150 \mathrm{ppb}\right)$ to 80 ppt $\left(\mathrm{O}_{3} \approx 300-400 \mathrm{ppb}\right)$. This is consistent with the view that acetone photolysis followed by reaction of peroxyacetyl radicals with $\mathrm{HO}_{2}\left(\mathrm{CH}_{3} \mathrm{CO}_{3}+\mathrm{HO}_{2} \rightarrow \mathrm{CH}_{3} \mathrm{COOH}+\mathrm{O}_{3}\right)$ is a possible in situ source of the lower stratospheric acetic acid [Singh et al., 1997]. Table 3 summarizes the mixing ratios of a number of select trace species as measured in the LS during SONEX. 
Here, as in the troposphere, Ox-organics are as much or more abundant than NMHC.

\section{Conclusions}

Oxygenated organic species are important sources of atmospheric free radicals and are intricately linked with processes of tropospheric ozone formation. With the exception of formaldehyde, the interest in oxygenated hydrocarbon is relatively recent. This study makes a case that these oxygenated species are ubiquitous and collectively are present in concentrations that are comparable to those of nonmethane hydrocarbons. They can participate in photochemistry of the troposphere in important ways and have complex biogenic sources which require better quantification and further study. In many cases, the sources and sinks of this group of chemicals are poorly known. It is likely that important new oxygenated species are present but have not yet been identified.

Acknowledgments. This research was funded by the NASA Atmosphenc Effects of Aviation Project (AEAP)/Subsonics Assessment (SASS) Program and the NSF Atmosphenc Chemistry Program. We thank R. Friedl, S Kawa, and D. Anderson, SASS Project Scientists, for their encouragement and support. Special thanks are due to James A. Ellers (SONEX Project Manager) and the NASA Ames DC-8 flight and ground crew for makıng this experiment a success.

\section{References}

Alvardo, A., E. Tuazon, S M. Aschmann, J. Arey, and R. Atkinson, Products and mechanisms of the gas phase reactions of $\mathrm{OH}$ radicals and $\mathrm{O}_{1}$ with 2-methyl-3-buten-2-ol, Atmos. Environ, in press, 1999.

Arnold, F., et al., Acetone in the upper troposphere and lower stratosphere: Impact on trace gases and aerosols, Geophys. Res. Lett., 24, 3017-3020, 1997

Crawford, J., et al , Assessment of upper tropospheric $\mathrm{HO}_{\boldsymbol{x}}$ sources over the tropical Pacific based on NASA GTE/PEM data: Net effect on $\mathrm{HO}_{x}$ and other photochemical parameters, J. Geophys. Res., 104, $16,255-16,273,1999$.

Demore, $W$, et al , Chemical kinetics and photochemical data for use in stratospheric modeling, Evaluation 12, JPL Publ, 97-4, 1997.

Fall, R., Biogenic emissions of volatile organic compounds from higher plants, in Reacative Hydrocarbons in the Atmosphere, edited by $\mathrm{N}$. Hewitt, pp 41-96, Academic, San Diego, Calif., 1999.

Ferronato, C., J. J. Orlando, and G. S. Tyndall, Rate and mechanism of the reaction reaction of $\mathrm{OH}$ and $\mathrm{Cl}$ with 2-methyl-3-buten-2-ol, $J$. Geophys. Res., 103, 25,579-25,586, 1998.

Fuelberg, H., et al., A meteorological overview of the SONEX period, $I$ Geophys Res., this issue.

Goldan, P. D., W. C. Kuster, F. C. Fehsenfeld, and S. A. Montzka, Hydrocarbon measurements in the southeastern United States: The Rural Oxidants in the Southem Environment (ROSE) program 1990, J. Geophys. Res., 100, 25,945-25,963, 1995.

Guenther, A. B., et al., A global model of natural volatile organic compound emissions, J. Geophys. Res., 100, 8873-8892, 1995.

Guenther, A B , et al., Natural emisions of non-methane volatile organic compounds, carbon monoxide and oxides of nitrogen from North America, Atmos. Environ., in press, 1999.

Harley, P., et al., Emissions of 2-methyl-3-buten-2-ol by pines: A potentially large source of reactive carbon to the atmosphere, $J$. Geophys. Res., 103, 25,479-25,486, 1998

Heikes, B., et al., Hydrogen peroxide and methylhydroperoxide distributions related to ozone and odd hydrogen over the North Pacific in the fall of 1991, J. Geophys Res., 101, 1891-1905, 1996.

Holzinger, R., C Warnke, A Hansel, A. Jordan, and W. Lindinger, Biomass burning as a source of formaldehyde, acetaldehyde, methanol, acetone, acetonitrile, and hydrogen cyanide, Geophys. Res. Lett., 26, 1161-1164, 1999.

Jacob, D. J., et al., Origin of ozone and $\mathrm{NO}_{X}$ in the tropical troposphere: A photochemical analysis of aurcraft observations over the South Atlantıc basin, J. Geophys. Res. I01, 24,235-24,250, 1996.
Jaeglé, L., et al., Observed $\mathrm{OH}$ and $\mathrm{HO}_{2}$ in the upper tropopshere suggest a major source from convective injection of peroxıdes, Geophys. Res. Lett., 24, 3181-3184, 1997.

Jaeglé, L., et al., Photochemistry of $\mathrm{HO}_{x}$ in the upper troposphere at northem midlatıtudes, $J$. Geophys. Res., this issue.

Keene, W. C., and J. N. Galloway, The biogeochemical cycling of formic and acetic acids through the troposphere: An overview of current understanding, Tellus, Ser. B, 40, 322-334, 1988

Keim, E. R., et al., Measurements of $\mathrm{NO}_{y}-\mathrm{N}_{2} \mathrm{O}$ correlation in the lower stratosphere. Latitudinal and seasonal changes and model comparisons, J. Geophys. Res., 102, 13,193-13,212, 1997.

Kirstıne, W., I. Galbally, Y Ye, and M. Hopper, Emissions of volatile organic compounds (including oxygenated species) from pasture, $J$. Geophys. Res., 103, 10,605-10,619, 1998.

Lamanna, M. S., and A. H. Goldstein, In situ measurements of $\mathrm{C}_{2} \cdot \mathrm{C}_{10}$ VOCs above a Sierra-Nevada pine plantation (including oxygenated species) from pasture, J. Geophys. Res, 104, 21,247-21,262, 1999.

Lawrence, M.G., P J. Crutzen, P.J. Rasch, B.E. Eaton, and N.M. Mahowald, A model for studies of troposphenc photochemistry: Description, global distributions, and evaluation, J. Geophys. Res., in press, 1999.

Lee, M., B. G. Heikes, and D. W. O'Sullivan, Hydrogen peroxide and organic hydroperoxides in the troposphere: A review, Atmos. Environ., in press, 1999.

Lindinger, W., A. Hansel, and A. Jordan, Proton-transfer-reaction mass spectrometery (PTR-MS): On-line monitoring of volatile organic compounds at pptv levels, Chem. Soc. Rev., 27, 347-354, 1998

Loyd, A., Tropsphenc chemistry of aldehydes, NBS Spec. Publ. U.S. $557,27-48,1979$

MacDonald, R. C., and R. Fall, Detection of substantial emissions of methanol from plants to the atmosphere, Atmos. Environ., Part A, 27, 1709-1713, 1993.

Murphy, D. M, D. S. Thomson, and M J. Mahoney, In situ measurements of organics, meteontic material, mercury, and other elements in aerosols at 5 to 19 kilometers, Science, 282, 1664-1669, 1998.

Reissell, A., C. Harry, S. Aschmann, R. Atkinson, and J. Arey, Formation of acetone from the $\mathrm{OH}$ radical- and $\mathrm{O}_{3}$-initiated reactions of a series of monoterpenes, J. Geophys. Res., I04, 13,869-13,879, 1999

Riemer, D., et ail, Observations of nonmethane hydrocarbons and oxygenated volatıle organic compounds at a rural site in the southeastern United States, J. Geophys. Res., 103, 28,11 I-28,128, 1998

Schumann, U., et al , Pollution from arcraft emissions in the North Atlantic flight comidor: Overview on the POLINAT projects, $J$ Geophys. Res., this issue, 1999.

Singh, H. B, Reactive nitrogen in the troposphere, Environ. Sci. Technol., $21,320-327,1987$.

Singh, H. B., et al., Acetone in the atmosphere: Distribution, sources and sinks, J. Geophys. Res., 99, 1805-1819, 1994.

Singh, H. B., M. Kanakidou, P. J. Crutzen, and D. J. Jacob, High concentrations and photochemical fate of oxygenated hydrocarbons in the global troposphere, Nature, 378, 50-54, 1995.

Singh, H. B., et al., Trace chemıcal measurements from the northern midlatitude lowermost stratosphere in early spring: Distributions, correlations, and fate, Geophys. Res. Lett., 24, 127-130, 1997.

Singh, H. B., A. Thompson, and H. Schlager, SONEX arrborne mission and coordinated POLINAT-2 actıvity: Overview and accomplishments, Geophys. Res Lett., 26, 3053-3056, 1999.

Talbot, R W., et al., Sources and sinks of formic, acetic, and pyruvic acids over central amazonia, J. Geophys. Res., 95, 16,799-16,811, 1990.

Talbot, R. W., et al., Carboxylic acids in the rural continental atmosphere over the eastern United States during the Shanandoah Cloud And Photochemistry Experiment, I. Geophys. Res., I00, 9335-9343, 1995.

Wang, Y, D. J. Jacob, and J. A. Logan, Global simulation of tropospheric $\mathrm{O}_{3}-\mathrm{NO}_{\chi}$-hydrocarbon chemistry, 1, Model formulation, $J$. Geophys Res , 103, 10,713-10,726, 1998a.

Wang, Y., D. J. Jacob, and J. A. Logan, Global simulation of tropospherıc $\mathrm{O}_{3}-\mathrm{NO}_{x}$-hydrocarbon chemistry, 2, Model evaluation and global ozone budget, $J$ Geophys. Res., 103, 10,727-10,755, 1998b.

Warneke, C., et al., Acetone, methanol, and other partially oxidized volatile organic emissions from dead plant matter by abiological processes: Significance for atmospheric $\mathrm{HO}_{x}$ chemistry, Global Biogeochem. Cycles, 13, 9-17, 1999.

Wennberg, P. O., et al., Hydrogen radicals, nitrogen radicals, and the 
production of ozone in the upper troposphere, Science, 279, 49-53, 1998

Wohlfrom, K -H., T. Hauler, F. Amold, and H. Singh, Acetone in the free troposphere and lower stratosphere: Aircraft-based IMRMS and GC measurements over the North Atlantic and a first comparison, Geophys. Res. Lett., 26, 2849-2852, 1999.

Yokelson, R J., et al., Emissions of formaldehyde, acetic acid, methanol, and other trace gases from biomass fires in North Carolina measured by Airborne Founer Transform Infrared Spectroscopy (AFTIR), $J$. Geophys Res, in press, 1999

F. Arnold and K Wohlfrom, Max Planck Institute fur Kernphysık, Postfach 103980, D-69029 Heidelberg, Germany.

E. Atlas and F. Flocke, Natıonal Center for Atmospheric Research,

1850 Table Mesa Dr., P. O. Box 3000, Boulder, CO 80307.

I. Bey, D. Jacob, and R. Yantosca, Harvard University, 29 Oxford St., Cambridge, MA 02138.
D. Blake and N. Blake, University of California, Physıcal Sciences Building, Irvine, CA 92697.

Y. Chen, Y. Fukui, H Singh, and A. Tabazadeh, NASA Ames Research Center, Moffett Field, CA 94035. (hsingh@mail.arc.nasa.gov)

G Gregory, G. Sachse, and S. Vay, NASA Langley Research Center, Hampton, VA 23681.

B. Heikes and J. Snow, University of Rhode Island, Center for Atmospheric Chemistry Studies, Narragansett, RI 02882.

Y. Kondo, Nagoya University, Honohara 3-13, Toyokawa, Aichi 442-8507, Japan.

R Talbot, University of New Hampshire, Durham, NH 03824.

(Received April 22, 1999; revised June 29, 1999. accepted July 7, 1999 ) 